\title{
Parental Monitoring and Adolescent Information Management: Associations with Cyber Risks
}

\author{
Elizabeth A. Yale \\ West Virginia University
}

Follow this and additional works at: https://researchrepository.wvu.edu/etd

\section{Recommended Citation}

Yale, Elizabeth A., "Parental Monitoring and Adolescent Information Management: Associations with Cyber Risks" (2013). Graduate Theses, Dissertations, and Problem Reports. 5014.

https://researchrepository.wvu.edu/etd/5014

This Thesis is protected by copyright and/or related rights. It has been brought to you by the The Research Repository @ WVU with permission from the rights-holder(s). You are free to use this Thesis in any way that is permitted by the copyright and related rights legislation that applies to your use. For other uses you must obtain permission from the rights-holder(s) directly, unless additional rights are indicated by a Creative Commons license in the record and/ or on the work itself. This Thesis has been accepted for inclusion in WVU Graduate Theses, Dissertations, and Problem Reports collection by an authorized administrator of The Research Repository @ WVU. For more information, please contact researchrepository@mail.wvu.edu. 
Parental Monitoring and Adolescent Information Management: Associations with Cyber Risks

Elizabeth A. Yale, M.A.

Thesis submitted to the Eberly College of Arts and Sciences

at West Virginia University

in partial fulfillment of the requirements

for the degree of

Master of Science

in

Psychology

Aaron Metzger, Ph.D. Chair
Amy Gentzler, Ph.D.
William Fremouw, Ph.D.
Department of Psychology

Morgantown, West Virginia

2013

Keywords: adolescence, parental monitoring, adolescent disclosure, cyberbullying, risky internet 


\section{Abstract \\ Parental Monitoring and Adolescent Information Management: Associations with Cyber Risks}

\section{Elizabeth A. Yale, M. A.}

The present study examined associations among internet and cellular phone specific parental monitoring strategies (rules, solicitation and indirect strategies), adolescent internet/phone information management strategies (disclosure and secrecy), and youth experience with internet risks (cyberbullying/victimization and risky internet behaviors). The sample included 155 adolescents $\left(12-18\right.$ years, $\left.M_{a g e}=14.38\right)$ and their parents (141 mothers, 51 fathers). Youth reported how often they disclosed or kept secret their internet and phone activities and their experience with internet risks. Parents reported how often they engaged in internet/phone specific monitoring strategies. Adolescents' time spent utilizing cell phones, but not time spent on general internet use was associated with cyberbullying, cyber victimization, and risky internet behaviors. Adolescent disclosure was associated with less risky internet/phone behaviors in mother-adolescent dyads. Parental rules and solicitation were not associated with teens’ internet risks. Mothers’ use of more covert strategies (e.g., reading text messages) was associated with more risky internet/phone behaviors for adolescent girls, whereas fathers' use of such covert strategies was associated with increased risky internet/phone behaviors for older adolescents. The findings point to the complex ways in which different facets of parentadolescent communication may serve to protect youth from the potential dangers of internet and cell phone use. 


\section{TABLE OF CONTENTS}

I. Introduction (pp. 1-5)

II. Method (pp. 5-9)
a. Participants (pp. 5-6)
b. Procedure (pp. 6-7)
c. Measures (pp. 7-9)

III. Results (pp. 9-11)

a. Preliminary Analyses (pp. 9-10)

b. Predictors of Adolescents' Cyberbullying, Cyber Victimization, and Risky Internet Use (p. 10)

c. Mother-adolescent dyads (pp. 10-11)

i. Risky Internet Behavior (pp. 10-11)

ii. Cyber Victimization (p.11)

iii. Cyberbullying Behavior (p. 11)

d. Father-adolescent dyads (p. 11)

i. Risky Internet Behavior (p. 11)

ii. Cyber Victimization (p.11)

iii. Cyberbullying Behavior (p. 11)

IV. Discussion (pp. 12-16)

V. References (pp. 17-21)

VI. Table 1: Parental Covert Internet/Phone Monitoring and Adolescent Risky Internet/Phone Items (p. 22)

VII. Table 2: Family Demographic Descriptive Statistics (p. 23) 
VIII. Table 3: Correlations for Key Study Variables (p. 24)

IX. Table 4: Mother hierarchical, and father stepwise regressions predicting adolescents' cyber risks (p. 25)

X. Figure 1: Associations between mothers' covert internet monitoring and adolescents' risky internet behaviors by adolescent gender interaction graph (p. 26)

XI. Figure 2: Associations between fathers' covert internet monitoring and adolescents' risky internet behaviors by adolescent age interaction graph (p. 27)

XII. Appendices (pp. 28-51)

a. Appendix A: Observational Measures (p. 28)

b. Appendix B: Parental Shared Knowledge Coding (pp. 29-30)

c. Appendix C: Originally Proposed Analyses (pp. 31-41)

i. Research Question 1 (pp. 31-33)

ii. Research Question 2 (pp. 34-36)

iii. Table 1: Adolescent Cyber Descriptive Statistics (p. 37)

iv. Table 2: Adolescent Experience With Cyberbullying (p. 38)

v. Table 3: Parents' Discussions of Shared Knowledge of Cyber Victimization (p.39)

vi. Table 4: Correlations Between Adolescent Demographic Variables, Cyber Victimization, and Cyberbullying (p.40)

vii. Table 5: Logistic Regression Predicting Mother-Adolescent Victim Dyads’ Shared Knowledge of Cyber Victimization (p. 41)

d. Appendix D: Parent Measures (pp. 42-45)

e. Appendix E: Adolescent Measures (pp.46-50) 
f. Appendix F: Discussion Cue Cards (p.51) 
With increasing technological advances, more adolescents rely on the Internet as their primary form of communication. ${ }^{1}$ Children and adolescents use the Internet to communicate with peers through chat rooms, email, instant messaging, and social networking sites while at school and at home. ${ }^{2}$ As of September 2012, 95\% of adolescents aged 12-17 were using the Internet, $80 \%$ owned a personal computer, and 78\% owned cell phones. ${ }^{3}$ A high percentage (74\%) of adolescents also report utilizing their mobile devices (i.e., phones and tablets) to access the Internet (based on data from a national poll of American youth as reported in Madden et al., 2013). However, while technological advances have multiple benefits for youth, increased use of cell phone and internet forms of communication also put adolescents at heightened risk of experiencing potential internet dangers, such as cyberbullying, sexting (sending text messages with sexual content), and talking to strangers online. ${ }^{2,4-6}$ The present study examined parents' internet/phone monitoring strategies and adolescents’ internet/phone information management strategies as family processes that may protect against cyber risks.

Previous research has found a number of demographic characteristics (i.e., age and gender) that predict high levels of adolescent internet use. For example, older teens are more likely to own a cell phone, have their own computers and use social networking sites, and adolescent girls are more likely than boys to use social networking sites. ${ }^{7}$ Other research has found consistent demographic predictors of cyberbullying behavior. ${ }^{8}$ For instance, increased electronic communication has been associated with increased risk of both cyberbullying and victimization. ${ }^{4,9,10}$ High rates of internet use has also been linked to other risky internet behaviors, such as receiving inappropriate messages. ${ }^{11}$ Much of the previous research on cyber risks has not distinguished between computer and cell phone internet use, which may be an important distinction given teens’ increased use of cell phones. 
Beyond identifying demographic and personality correlates of internet activity and risky internet use, it is also important for research to identify social factors that can protect teens from the dangers involved with Internet and cell phone use. For instance, family processes such as dimensions of parent-adolescent communication may play an important role in protecting teens by increasing parents' knowledge of what their teens are doing online. Research outside of Internet use has found consistent links between parental knowledge of teens’ activities and whereabouts and fewer adolescent problem behaviors including delinquency and substance use. $^{12,13}$ Recently, developmental research has noted the importance of considering the source of parental knowledge, distinguishing knowledge gained through parental monitoring behaviors from adolescents’ own willing disclosure. ${ }^{15}$

A burgeoning body of research indicates that compared to parental monitoring efforts, adolescent disclosure is more strongly associated with both increased parental knowledge and decreased adolescent problem behavior. ${ }^{14-16}$ However, adolescents’ communication goals do not always include increasing their parents' knowledge. Instead, adolescents are often motivated to keep information about some of their activities secret from parents for both personal as well as practical reasons (i.e., avoid getting into trouble). ${ }^{17,18}$ Consequently, teens report freely disclosing to their parents about some issues and keeping other information secret from parents. $^{19,20}$ Moderate correlations have been found between adolescent disclosure and secrecy suggesting they are distinct constructs. Whereas disclosure has been associated with positive outcomes including less rule breaking, secrecy is consistently associated with physical and mental health problems and higher rates of delinquency. ${ }^{19,}$ 21, 22

In addition to distinguishing disclosure and secrecy, recent research has pointed to the incremental utility of considering what an adolescent is disclosing or keeping secret. ${ }^{18}$ For 
instance, disclosure/secrecy related to potentially risky behaviors has been found to be more strongly related to subsequent engagement in problem activities. ${ }^{23}$ These findings suggest adolescent disclosure about their Internet and cell phone activities may account for unique variance in teens' experiences with cyber risks. Researchers have indicated that adolescents who told their parents what they did on the Internet reported writing fewer aggressive online messages. ${ }^{24}$ However, this previous research did not distinguish disclosure from secrecy, and did not consider additional problematic outcomes, such as cyber victimization or risky internet and phone behaviors.

As noted above, previous research has found that parental monitoring behaviors may be less strongly associated with positive adolescent outcomes than adolescent disclosure. ${ }^{15}$ However, it is unclear whether parenting behaviors which are specific to Internet and cell-phone use are protective against risks associated with the Internet. Parents recognize the potential dangers that accompany adolescents’ increased access to the Internet and cell phones. ${ }^{7}$ To protect their teens against these risks, parents engage in a variety of behaviors including setting rules about Internet use (behavioral control), asking their children about usage (solicitation), tracking websites (covert monitoring), and relying on teen spontaneous disclosure. ${ }^{24-26}$ Although parents overestimate how well they monitor their teens' Internet use and underestimate how frequently their own adolescents engage in risky internet behaviors, ${ }^{25}$ previous research hints at the possibility that internet/phone specific parenting behaviors may protect against cyber risk. Increased parental Internet monitoring has been associated with lower rates of stranger contact and reduced engagement in cyberbullying behaviors, but it was not associated with cyber victimization. ${ }^{2,5,11}$ However, a great deal of past research in this area has relied on "monitoring” scales that measured parental knowledge (e.g., "How often do your parents know where you are 
when you are not in school?”) ${ }^{27}$ rather than assessing actual parental behaviors. In addition, little research distinguished between specific types of parenting behaviors regarding internet and cell phone use (rules vs. solicitation).

When parents believe that they are not receiving adequate information about their teens' internet/phone behaviors, they may eschew direct parenting approaches such as solicitation, and instead engage in more indirect strategies. For instance, parents may covertly monitor their adolescents’ Internet and cell phone use by “snooping” in their bedrooms to read text messages on cell phones, tracking websites on their laptops, monitoring social networking sites (Facebook), or checking their e-mails. Research has found that teens react negatively to parents' indirect or “covert” parenting approaches and view such parenting as an invasion of their privacy. ${ }^{28}$ Moreover, such covert monitoring behaviors have been linked with lower levels of parental knowledge about general behaviors. ${ }^{29}$ However, it is unclear whether parents' covert monitoring strategies that are internet-specific are protective against youth cyber risks. Compared to other adolescent behaviors, Internet and cell phone use may be a domain of teenage behaviors that is easier to monitor covertly because much of their online behaviors are now occurring on mobile devices that are always with them. ${ }^{3}$ Previous research has examined how often parents check which websites teens have visited but have not measured other covert strategies such as reading text messages and e-mails and checking Facebook. ${ }^{25}$ Although previous research suggests that teens do not like parents' covert monitoring, it is less clear whether parents' use of internet/cell-phone covert strategies are at all beneficial for decreasing cyber risks.

Researchers have found that parental knowledge and use of strict monitoring strategies tends to decrease with age, and older adolescents disclose less to parents than younger teens. ${ }^{12,30}$ 
Compared to sons, parents’ relationship with daughters entails greater knowledge, and higher levels of both parental monitoring, and adolescent disclosure. ${ }^{12,22,31}$ General parenting research has also found that mothers tend to have more knowledge of their adolescents' behaviors and receive higher levels of disclosure than fathers. ${ }^{20}$ Internet research has found similar results with mothers having more accurate knowledge of adolescents' internet use compared to fathers. ${ }^{25}$ The above findings may suggest that parental behaviors and adolescent communication may be differentially associated with youth cyber risks as a function of adolescents’ age and gender.

The present study examined associations between parent-reported monitoring behaviors (rules, solicitation, covert), adolescent-reported information management (disclosure and secrecy), and adolescents’ problematic internet/cell-phone behavior (cyberbullying/victimization, risky internet behaviors). Based on previous research, it was hypothesized that adolescent disclosure and secrecy would be more strongly associated with internet and phone dangers than parents’ internet monitoring strategies. Analyses explored whether adolescent age and both parent and adolescent gender moderated associations between monitoring strategies, disclosure/secrecy, and internet risks. Finally, the present study utilized a more nuanced measure of adolescents' Internet use that distinguished between Internet accesses through computers vs. cell phones in order to account for teens’ increased Internet use on mobile devices.

\section{Method}

\section{Participants}

One hundred and sixty-one adolescents and their adult caregivers (145 mother-adolescent dyads, 53 father-adolescent dyads) were recruited as part of a larger study of family communication processes. Adolescents and their parents were recruited through a local pediatrics clinic and from local youth organizations, high schools and churches in and around a 
mid-Atlantic town. Participants received monetary compensation for their participation. Two adolescents reported that they do not use the Internet, and were removed from further analyses along with their parents. Four parent-adolescent dyads were removed from the sample because the adolescents reported, "never doing” the internet behavior for all disclosure or secrecy items. Thus, the analytic sample consisted of 155 adolescents ages $12-18(M=14.38, S D=1.72)$, primarily Caucasian/White (80\%), and 60\% were female.

Adolescents participated in a short discussion task with their parents (both mothers and fathers if possible) before all participants completed questionnaires. Twenty-four percent of adolescents participated with both parents $(n=37)$ and $76 \%$ participated with one parent $(n=$ 118). The majority of teens (86\%) who participated with one parent participated with their mothers $(n=102), 12 \%(n=14)$ participated with their fathers, and $2 \%(n=2)$ participated with another relative (aunt, grandparent). The analytic sample consists of 155 adolescents and their parents: 141 with mothers and 51 with fathers. For complete demographic information see Table 2.

\section{Procedure}

Data were primarily collected in families’ homes (71.4\%), though some families (28.6\%) chose to participate at the research lab of the study’s primary investigator or in a public place, such as a church. However, no study variables differed as a function of location. Parents gave informed consent for themselves and permission for their adolescent, while the adolescent gave informed assent. After participating in a short dyadic discussion task, adolescents and parents completed questionnaires in separate rooms with research team members present to answer questions. Research assistants read the survey to twelve (7.5\%) of the adolescents, and partially 
read to four (2.5\%). Adolescents who were read the survey did not differ on any of the key study variables.

\section{Questionnaire Measures}

\section{Parent Report.}

Solicitation about internet/phone use. Parents reported how often they ask their adolescents about the teens’ Internet and cell phone behaviors (How often do you talk to your teenager or ask about... what he/she talks about on the phone with friends; if he/she is talking to individuals online who he/she doesn't know). This scale included 7 items scored on a 5-point Likert-type scale $(1=$ Never to 5 = Always $)$. Higher scores indicated that parents consistently ask their adolescents about Internet behaviors, whereas lower scores indicated parents infrequently ask their adolescent for information ( $\alpha=.90,7$ items).

Family rules about internet/phone use. The extent to which the family has rules for Internet and phone use was measured through parents' report on 4 items, for example “How long your child is allowed to be online." Items were answered on a 5-point Likert-type scale (1 = No rules to 5 = Firm, clear rules), with higher scores indicating the family has clear rules, and lower scores indicating few or no rules $(\alpha=.78,4$ items).

Covert monitoring of teens' internet/phone use. Covert monitoring was assessed through parent report of whether they use indirect strategies to gain information about their adolescents’ Internet behaviors. The scale was developed to examine ways in which parents utilize a variety of covert monitoring strategies, such as "Do you use social networking sites (such as FACEBOOK) to monitor your child's behavior?" The four items included in this scale were answered in a yes/no format $(1=$ yes, $0=n o)$. Scores were summed with higher scores 
indicating greater use of indirect strategies (KR20 = .70, 4 items). All items can be found in Table 1.

\section{Adolescent Report.}

Internet use. Adolescents' average Internet use was measured by two questions that asked adolescents to report how many hours (None, Less than 1, 1-2, 3-5, 6+) they spend using the Internet on an average weekday and weekend. An Internet use variable was created by averaging responses for the weekday and weekend ( $\alpha=.80,2$ items).

Cell phone use. Cell phone use was measured through adolescent reports of how many hours they spend using their cell phones during an average weekday and weekend, as well as texting, making calls, and surfing the Internet (None, Less than 1, 1-2, 305, 6+). A cell phone use variable was created by averaging answers to the five questions ( $\alpha=.88,5$ items).

Adolescent disclosure/secrecy about internet/phone use. Adolescents reported how often they discussed their internet/phone related behavior (5-items) with parents without parents asking as well as how often they kept those internet/phone behaviors secret (5-items; e.g. types of pictures and comments you put on your social networking site). Responses were reported on a 5point Likert-type scale $(1=$ Never to $5=$ Always $)$ with higher scores on disclosure items indicating more adolescent disclosure about Internet and higher scores on secrecy items indicating more secrecy. For both the disclosure and secrecy scales, adolescents were also given the option to report that they do not engage in the internet behavior ( $6=$ I don't do this). Similar to previous research that allowed adolescents to respond that they "don't do" the activity, Cronbach's alpha could not be computed for this measure. ${ }^{18,32}$ Due to a majority of adolescents not answering and because it measured an extreme risk behavior while other items did not, the 
item "if you visit adult websites” was dropped from the original disclosure and secrecy scales, resulting in the 5-item scales.

Cyberbullying behavior and cyber victimization. The present study utilized a modified version of the Internet Experiences Questionnaire (IEQ) that was developed by previous researchers to assess experiences with various forms of cyberbullying, including perpetration and victimization. $^{8}$ Adolescents were asked how often "in the last year" they have engaged in cyberbullying behaviors, and experienced different forms of cyber victimization. Adolescents reported on 7-items that measured frequency of experiencing victimization $(\alpha=.89)$, and 5-items that measured acting as the perpetrator of cyberbullying behaviors $(\alpha=.72)$. Answers were reported according to frequency $(0,1,2-3,4-7,8-14$, and 15 or more) and were separated into two scales, cyberbullying and cyber victimization. An example item is "How many times have you sent/received harassing, mean, or nasty text-messages in the last year?”

Risky internet behavior. Adolescents reported how often they engaged in risky internet behaviors, including sexting and adding friends on Facebook whom they have never met offline “in the last 30 days”. Participants answered 6 questions about their frequency of engagement in risky internet behaviors $(0,1,2-3,4-6,7-10,11+$, Table 2$)$. Responses were combined into one item with higher scores indicating more risky internet use ( $\alpha=.75,6$ items).

\section{Results}

\section{Preliminary Analyses}

Log transformations were performed for the cyber victimization, engagement in cyberbullying and risky internet behavior scales to reduce significant skewness. Transformed variables were utilized in all subsequent analyses. Bivariate associations for key study variables can be found in Table 3. Consistent with previous research, girls and older adolescents spent 
more time on cell phones, and older adolescents had fewer internet/cell phone rules and disclosed less. Mothers reported increased use of solicitation and covert monitoring strategies with increases in teens' cell phone use (but not internet use), whereas fathers reported increased rules with more Internet use (but not cell use).

\section{Predictors of Adolescents’ Cyberbullying, Cyber Victimization, and Risky Internet Use}

Associations among parents’ internet/phone monitoring strategies, adolescents’ internet/phone information management strategies, and risky internet (cyber victimization, cyberbullying, and risky internet use) were assessed utilizing separate multiple regression analyses for mother-adolescent dyads and father-adolescent dyads. In the first step adolescent reports of the dependent variable were regressed on adolescent age, gender, and internet/phone use. Adolescent information management strategies (disclosure and secrecy) and parental internet/phone monitoring strategies (rules, solicitation, and covert) were entered in the second step. In the final step of the model, adolescent gender $\mathrm{X}$ parental monitoring strategies and gender $\mathrm{X}$ adolescent information management strategies were entered, as well as adolescent age $\mathrm{X}$ parental monitoring strategies and age $\mathrm{X}$ adolescent information management strategies. Due to the small number of father-adolescent dyads, stepwise multiple regressions were utilized, with follow up hierarchical regressions to examine moderator variables. Results for mother and father models are presented in Table 4.

\section{Mother-adolescent dyads.}

Risky internet behavior. Older adolescents and those who spend more time on their cell phones were more likely to engage in risky internet behaviors. Adolescents who engaged in higher levels of disclosure about their internet and phone use engaged in less risky internet behaviors. Finally, a significant covert Internet monitoring by gender interaction emerged. 
Higher rates of mothers' covert monitoring was associated with more risky Internet use for girls, but not boys (girls: $\mathrm{B}=.09, \mathrm{SE}=.05, p=.04$; Figure 1 ).

Cyber victimization. Adolescent gender and cell phone use were the only significant predictors of cyber victimization. Girls and adolescents who engaged in more cell phone use reported more victimization.

Cyberbullying behavior. Results indicated adolescent age and cell phone use as predictors of engagement in cyberbullying behavior. Older adolescents and adolescents who spent more time on their cell phones were more likely to report engagement in cyberbullying behaviors.

\section{Father-adolescent dyads.}

Risky internet behavior. Similar to findings for mothers, older adolescents and those who spend more time on their cell phones were more likely to engage in risky internet behaviors. A main effect of fathers' covert internet monitoring was qualified by a significant covert monitoring by age interaction; higher rates of fathers’ covert internet/phone monitoring was associated with more risky internet use for older adolescents, but not younger adolescents (older teens: $\mathrm{B}=.32$, S.E. $=.07, p<.001$; Figure 2).

Cyber victimization. Increased paternal solicitation was associated with higher levels of teen-reported victimization.

Cyberbullying behavior. Adolescents' cell phone use accounted for a significant amount of variance in cyberbullying behaviors; increased time spent on a cell phone was associated with increased engagement in cyberbullying. 


\section{Discussion}

Adolescents’ increased use of technology and online forms of communication has also increased their vulnerability to dangers associated with using the Internet. The goal of the present study was to assess parents’ internet/phone monitoring behaviors and adolescents’ internet/phone information management strategies as potential protective factors for adolescents’ internet risks. Findings pointed to time spent on cell phones (but not general internet use) as a potentially important risk factor. Adolescent disclosure predicted less risky internet/phone use while parents' use of internet monitoring strategies were not associated with reduced cyber risks. In fact, findings indicate parents' use of invasive internet/phone monitoring may be counterproductive, especially for fathers of older adolescents and for mothers with their daughters.

Adolescent disclosure has been consistently associated with positive developmental outcomes including fewer problem behaviors. ${ }^{15}$ In the current study and consistent with prior research, higher rates of adolescent disclosure to mothers about Internet and cell phone use was associated with less risky internet/phone use. Adolescents who believe that they can openly talk to their mothers about what they do on the Internet and their cell phones may be less interested in engaging in risky internet behaviors. However, could also potentially indicate that teens who engage in problematic internet/phone behaviors do not openly share what they are doing online with their parents. Interestingly, adolescents' keeping internet/phone behaviors secret from their parents was not associated with cyber risks. Previous research on adolescent communication concerning general behaviors has found stronger evidence for a secrecy/problem behavior link than a disclosure/problem behavior link. ${ }^{21}$ However, the present findings indicate that adolescent free discussion of their internet and cell phone activities may be a more vital mechanism for 
protecting against cyber risks than secrecy. Cyber risks may be a different realm of harmful behaviors than substance use or delinquency, which may indicate the importance of different family communication mechanisms than typically seen.

While teen initiation regarding their internet/phone behavior was protective, the present findings were consistent with previous research indicating that parents’ active monitoring strategies may be counterproductive to protecting adolescents from negative outcomes. ${ }^{15}$ Mothers' reported use of rules and solicitation were unrelated to adolescents' cyber risk behavior. For fathers, solicitation about Internet and cell phone use was actually associated with greater cyber victimization. This could indicate paternal reactions to teens' victimization, which may prompt fathers to more vigilantly monitor their teens’ internet activities and more frequently ask for more information about what their teens are doing online. These findings are based on cross-sectional associations, but this pattern hints at the possibility that fathers' sensitivity to adolescent victimization may be an important factor in protecting teens from future victimization. At the very least, the current study indicates that parental solicitation concerning their teens' Internet and cell phone may not be an effective strategy for protecting teens' from cyber risks.

However, parents’ use of covert internet/cell phone monitoring strategies may be even less helpful. In order to protect their adolescents from engaging in risky cyber behaviors, parents’ may engage in behaviors such as tracking websites, reading teens’ text messages and email for information. The present findings suggest that this form of monitoring may hinder parents’ goals of protecting their teens. Within mother-adolescent dyads, increased covert monitoring was associated with daughters' but not sons' greater engagement in risky internet/phone behaviors. Adolescent daughters are more likely than sons to disclose 
information to their mothers and may view mothers’ sneaky monitoring behaviors more negatively because they believe that their mothers should trust them more. ${ }^{30}$ Thus, when mothers engage in more sneaky monitoring strategies rather than communication daughters may react with more risky internet/phone use. ${ }^{33}$ Increased covert monitoring by fathers was associated with increased risky internet/phone use for older but not younger adolescents. Adolescents believe that parents' authority to control adolescents’ personal lives decreases over time, and when parents exert restrictive control they may feel that their privacy has been violated. ${ }^{28}$ Therefore, fathers' use of indirect methods such as checking older adolescents' emails and text messages may actually fuel engagement in risky internet/phone behaviors rather than decrease its frequency. However, the above findings may also indicate potential parental reactions to their adolescents' engagement in risky internet/phone behaviors. When parents find out that their teens have been engaging in risky internet/phone behaviors they may seek more information through covert monitoring strategies.

Outside of parent-adolescent communication, the current study also points to the importance of measurement precision when assessing teen media behavior. Although prior research has indicated that time spent online is an important predictor of risky behavior including cyberbullying/victimization, ${ }^{4,10,25}$ the present findings indicate the importance of separating cell phone use from general Internet use. Recent research suggests that more adolescents are relying on their cell phones as a primary means of accessing the Internet. ${ }^{3}$ In the present study, time spent on a cell phone and not general Internet use was predictive of engagement in cyberbullying, cyber victimization, and risky internet behaviors. Unlike computers that can be kept in public areas at home or school, adolescents' cell phones are always with them, consequently increasing time spent on the Internet as well as vulnerability to cyber risks. 
Additionally, much of adolescents' cell phone use may occur outside of the home, which decreases parents' ability to monitor and may partially explain the ineffectiveness of parents’ internet/phone monitoring strategies found in the current study. Future research should employ more nuanced measures of the devices adolescents are utilizing to access the internet and assess other potential correlates of cyber risks related to accessing the internet on mobile devices, including surfing websites vs. visiting social networking sites and location of primary use (i.e. home vs. school).

The current study has several strengths including a multi-informant approach that included both mothers and fathers. However findings must be interpreted in light of potential weaknesses. The study used self-report measures, which are vulnerable to social desirability and other biases. A cross-sectional design was utilized limiting causal interpretations. The sample of fathers was considerably smaller than the number of mother reporters, which limited the ability to examine the full regression models for father-adolescent dyads. A high percentage of participating mothers and fathers had graduated college or attained post-graduate degrees, which could limit generalizability to less well-educated populations. Additionally, the present study utilized new measures of parental covert internet/phone monitoring measures and risky internet/phone measures, and further research is needed to fully test their utility and psychometric properties.

Despite these limitations, the present study has multiple implications for future research. Findings suggest the importance of family communication about Internet and cell phone behaviors, and the potential limitations of parents' employing sneaky monitoring strategies. Future research should explore additional family processes that facilitate an environment in which teens feel comfortable talking about their cyber behaviors. Open communication and 
parents’ positive responses to disclosure are components of families that may both directly predict adolescent outcomes as well as mediate associations between family process variables and adolescent cyber risks. ${ }^{34}$ Such processes may be especially important protective factors for cyberbullying and cyber victimization for which the proposed family process variables were not significant predictors.

The present study supports previous research indicating the importance of adolescent disclosure in protecting adolescents from potentially negative outcomes. Parents may best protect their teens by working to foster a positive family atmosphere that is conducive to teens' openly discussing their Internet and cell phone behaviors. ${ }^{16,35}$ The present findings suggest that even within a domain of behaviors in which teens engage at high levels and that introduce a wide range of risks, adolescent communication about what they are doing is linked with positive outcomes. 


\section{References}

1. Lenhart A. Teens, smartphones and texting. Washington, DC: PEW Internet \& American Life Project 2012. http://pewInternet.org/Reports/2012/Teens-and-smartphones.aspx

2. Ybarra ML, Mitchell KJ. Online aggressor/targets, aggressors, and targets: A comparison of associated youth characteristics. Journal of Child Psychology and Psychiatry 2004: 45: 1308-16.

3. Madden M, Lenhart A, Duggan M, Cortesi S, Gasser U. Teens and technology 2013. Washington, DC: PEW Internet \& American Life Project 2013. http://www.pewinternet.org/ /media//Files/Reports/2013/PIP_TeensandTechnology2013. pdf

4. Ybarra ML, Mitchell KJ, Korchmaros JD. National trends in exposure to and experiences of violence on the Internet among children. Pediatrics 2011: 128: e1376-el86.

5. Williams AL, Merten MJ. iFamily: Internet and social media technology in the family context. Family and Consumer Sciences Research Journal 2011: 40: 150-70.

6. Valcke MM, De Wever BB, Van Keer HH, Schellens TT. Long-term study of safe internet use of young children. Computers \& Education 2011: 57(1): 1292-1305.

7. Brenner J. Commentary Pew Internet: Teens. Washington, DC: PEW Internet \& American Life Project 2012. http://pewInternet.org/Commentary/2012/April/Pew-InternetTeens.aspx\#

8. Schenk AM, Fremouw W J. Prevalence, psychological impact, and coping of cyber victims among college students. Journal of School Violence 2012: 11: 21-37.

9. Hinduja S, Patchin JW. Cyberbullying: An exploratory analysis of factors related to offending and victimization. Deviant Behavior 2008: 29: 129-56. 
10. Mishna F, Khoury-Kassabri M, Gadalla T, Daciuk J. Risk factors for involvement in cyber bullying: Victims, bullies and bully-victims. Children and Youth Services Review 2012: 34: 63-70.

11. Liau AK, Khoo A, Ang PH. Factors influencing adolescent engagement in risky Internet behavior. Cyberpsychology and Behavior 2005: 8: 513-20.

12. Dishion TJ, McMahon RJ. Parental monitoring and the prevention of child and adolescent problem behavior: A conceptual and empirical formulation. Clinical Child and Family Psychology Review 1998: 1(1): 61-75.

13. Wang MT, Dishion TJ, Stormshack EA, Willett JB. Trajectories of family management practices and early adolescent behavioral outcomes. Developmental Psychology 2011: 47(5): 1324-134.

14. Cumsille P, Darling N, Martinez ML. Shading the truth: Adolescents’ decisions to avoid issues, disclose, or lie to parents. Journal of Adolescence 2010: 33: 285-296.

15. Kerr M, Stattin H, Burk WJ. A reinterpretation of parental monitoring in longitudinal perspective. Journal of Research on Adolescence 2010: 20(1): 39-64.

16. Stattin H, Kerr M. Parental monitoring: A reinterpretation. Child Development 2000: 71(4): 1072-85.

17. Darling N, Cumsille P, Caldwell LL, Dowdy B. Predictors of adolescents’ disclosure to parents and perceived parental knowledge: Between- and within- person differences. Journal of Youth and Adolescence 2006: 35: 667-678.

18. Smetana JG, Villalobos M, Tasopoulos-Chan M, Gettman DC, Campione-Barr N. Early and middle adolescents’ disclosure to parents about activities in different domains. Journal of Adolescence 2009: 32: 693-713. 
19. Laird RD, Marrero MD. Information management and behavior problems: Is concealing misbehavior necessarily a sign of trouble? Journal of Adolescence 2010: 33 (3): 297308.

20. Smetana JG, Metzger A, Gettman DC, Campione-Barr N. Disclosure and secrecy in adolescent-parent relationships. Child Development, 2006: 77(1): 201-17.

21. Frijns T, Keijsers L, Branje S, Meeus W. What parents don't know and how it may affect their children: Qualifying the disclosure-adjustment link. Journal of Adolescence 2010: 33: 261-270.

22. Willoughby T, Hamza CA. A longitudinal examination of the bidirectional associations among perceived parenting behaviors, adolescent disclosure and problem behavior across the high school years. Journal of Youth and Adolescence 2011: 40: 463-478.

23. Metzger A, Wakschlag LS, Anderson R, Darfler A, Price J, Flores Z, Mermelstein R. Information management strategies within conversations about cigarette smoking: Parenting correlates and longitudinal associations with teen smoking. Developmental psychology 2012.

24. Law DM, Shapka JD, Olson BF. To control or not to control? Parenting behaviours and adolescent online aggression. Computers in Human Behavior 2010: 26: 1651-56.

25. Liau AK, Khoo A, Ang PH. Parental awareness and monitoring of adolescent Internet use. Current Psychology 2008: 27: 217-33.

26. Valcke M, Bonte S, De Wever B, Rots I. Internet parenting styles and the impact on Internet use of primary school children. Computers \& Education 2010: 55: 454-64.

27. Patterson GR, Dishion TJ. Contributions of families and peers to delinquency. Criminology 1985: 23: $63-79$. 
28. Hawk ST, Hale III WW, Raaijmakers QAW, Meeus W. Adolescents’ perceptions of privacy invasion in reaction to parental solicitation and control. The Journal of Early Adolescence 2008: 28: 583-608.

29. Hawk ST, Keijsers L, Frijns T, Hale W, Branje S, Meeus W. "I Still Haven't Found What I'm Looking For” Parental Privacy Invasion Predicts Reduced Parental Knowledge. Developmental Psychology 2012.

30. Keijsers L, Branje SJT, Frijns T, Finkenauer C, Meeus W. Gender differences in keeping secrets from parents in adolescence. Developmental Psychology 2010: 46(1): 293-98.

31. Kerr M, Stattin H. What parents know, how they know it, and several forms of adolescent adjustment: Further support for a reinterpretation of monitoring. Developmental Psychology 2000: 36: 366-80.

32. Tasopoulos-Chan M, Smetana JG, Yau JP. How much do I tell thee? Strategies for managing information to parents among American adolescents from Chinese, Mexican and European backgrounds. Journal of Family Psychology 2009: 23: 364 - 74.

33. Keijsers L, Branje S, Hawk ST, Schwartz S J, Frijns T, Koot HM, Meeus W. Forbidden friends as forbidden fruit: Parental supervision of friendships, contact with deviant peers, and adolescent delinquency. Child Development 2012: 83(2): 651-66.

34. Tilton-Weaver L, Kerr M, Pakalniskeine V, Tokic A, Salihovic S, Stattin H. Open up or close down: How do parental reactions affect youth information management? Journal of Adolescence 2010: 33: 333 - 346.

35. Crouter AC, Head MR. Parental monitoring and knowledge of children. Handbook of parenting: Vol. 3: Being and becoming a parent 2002: 461-483. 
36. Cui M., Conger R. Parenting behavior as mediator and moderator of the association between marital problems and adolescent adjustment. Journal of Research on Adolescence 2008: 18: 261-284.

37. Cicchetti D., Bronen R., Spencer S., Haut S., Berg A., Oliver P., Tyrer, P. Rating scales, scales of measurement, issues of reliability resolving some critical issues for clinicians and researchers. The Journal of Nervous and Mental Disease 2006: 19: 557-564.

38. Wakschlag LS., Metzger A., Darfler A., Ho J., Mermelstein R., Rathouz PJ. The family talk about smoking (FTAS) paradigm: New directions for assessing parent-teen communications about smoking. Nicotine \& Tobacco Research 2011: 13: 103-112.

39. Agatston PW, Kowalski R, Limber, S. Students' perspectives on cyber bullying. Journal of Adolescent Health 2007: 41: S59-S60. 


\section{Table 1}

Parental covert internet/phone monitoring and adolescent risky internet/phone items

\begin{tabular}{|c|c|c|}
\hline Reporter: Measure & & Questionnaire Items \\
\hline Parent Report: Covert Monitoring & & $\begin{array}{l}\text { 1. Do you use social networking sites (such as } \\
\text { FACEBOOK) to monitor your child's behavior? } \\
\text { 2. Do you monitor your child's cell phone use? } \\
\text { 3. Have you ever checked your child's email to get } \\
\text { information about what your teen is doing or saying to } \\
\text { friends? } \\
\text { 4. Have you ever checked your child's cell phone to get } \\
\text { information about what your teen is doing or saying to } \\
\text { friends? }\end{array}$ \\
\hline Teen Report: Risky Internet/Phone Behaviors & $\begin{array}{l}\text { How often in the } \\
\text { last } 30 \text { days... }\end{array}$ & $\begin{array}{l}\text { 1. You have posted photos on Facebook involving } \\
\text { alcohol or drug use } \\
\text { 2. You have posted sexually suggestive photos of } \\
\text { yourself or your friends on Facebook } \\
\text { 3. You have added Friends on Facebook whom you have } \\
\text { never met offline } \\
\text { 4. You have texted/sexted sexual photos } \\
\text { 5. You have texted/sexted sexual messages } \\
\text { 6. You have texted mean or hurtful messages }\end{array}$ \\
\hline
\end{tabular}


PARENTAL MONITORING, YOUTH DISCLOSURE, AND CYBER RISK

Table 2

Family Demographic Descriptive Statistics

\begin{tabular}{|c|c|c|c|c|c|c|}
\hline \multirow[b]{2}{*}{ Measure } & \multicolumn{2}{|c|}{$\begin{array}{c}\text { Adolescents } \\
(N=155)\end{array}$} & \multicolumn{2}{|c|}{$\begin{array}{l}\text { Mothers } \\
(N=141)\end{array}$} & \multicolumn{2}{|c|}{$\begin{array}{l}\text { Fathers } \\
(N=51)\end{array}$} \\
\hline & M (SD) & $\%$ & $M(S D)$ & $\%$ & $M(S D)$ & $\%$ \\
\hline Age & $14.38(1.72)$ & & $43.48(6.78)$ & & $45.75(8.24)$ & \\
\hline \multicolumn{7}{|l|}{ Gender } \\
\hline $\begin{array}{l}\text { Males } \\
\text { Females }\end{array}$ & & $\begin{array}{l}40 \\
60\end{array}$ & & & & \\
\hline \multicolumn{7}{|l|}{ Ethnicity } \\
\hline $\begin{array}{l}\text { Caucasian/White } \\
\text { African-American/Black } \\
\text { Asian American/Pacific Islander } \\
\text { Hispanic/Latino } \\
\text { Biracial } \\
\text { Native American } \\
\text { Missing/failed to report }\end{array}$ & & $\begin{array}{r}80.6 \\
7.7 \\
2.6 \\
2.6 \\
5.2 \\
.6 \\
.6\end{array}$ & & $\begin{array}{r}92.2 \\
4.3 \\
.7 \\
1.4 \\
1.4\end{array}$ & & $\begin{array}{r}90.2 \\
2.0 \\
2.0 \\
2.0 \\
3.9\end{array}$ \\
\hline \multicolumn{7}{|l|}{ Relationship to adolescent } \\
\hline $\begin{array}{l}\text { Birth } \\
\text { Step-parent } \\
\text { Adoptive } \\
\text { Grandparent } \\
\text { Other relative } \\
\text { (aunt, sister, uncle, brother, cousin) } \\
\text { Missing/Failed to Report }\end{array}$ & & & & $\begin{array}{r}93.6 \\
2.1 \\
1.4 \\
.7 \\
.7 \\
1.4\end{array}$ & & $\begin{array}{r}80.4 \\
11.8 \\
5.9 \\
2.0\end{array}$ \\
\hline \multicolumn{7}{|l|}{ Education } \\
\hline $\begin{array}{l}\text { Completed } 8^{\text {th }} \text { Grade } \\
\text { Completed High School } \\
\text { Completed College } \\
\text { Business or Technical School } \\
\text { Graduate Degree } \\
\text { (Doctor, Lawyer, PhD) } \\
\text { Missing/Failed to Report }\end{array}$ & & & & $\begin{array}{r}2.1 \\
17.0 \\
37.6 \\
12.1 \\
29.8 \\
1.4\end{array}$ & & $\begin{array}{r}2.0 \\
29.4 \\
31.4 \\
5.9 \\
29.4 \\
2.0\end{array}$ \\
\hline $\begin{array}{l}\text { Marital Status } \\
\text { Married } \\
\text { Divorced/Separated } \\
\text { Living with a Romantic Partner } \\
\text { Widowed } \\
\text { Single, Never Married } \\
\text { Missing }\end{array}$ & & & & $\begin{array}{r}72.3 \\
17.7 \\
2.1 \\
2.1 \\
3.5 \\
2.1\end{array}$ & & $\begin{array}{r}88.2 \\
9.8 \\
2.0\end{array}$ \\
\hline Adolescent internet/phone disclosure & $2.57(1.23)$ & & & & & \\
\hline Adolescent internet/phone secrecy & $2.47(1.18)$ & & & & & \\
\hline Parental internet/phone rules & & & $3.41(1.02)$ & & $3.52(0.98)$ & \\
\hline Parental internet/phone solicitation & & & $3.24(1.11)$ & & $3.18(1.02)$ & \\
\hline Parental internet/phone covert monitoring & & & $2.58(1.38)$ & & $2.25(1.37)$ & \\
\hline
\end{tabular}


Table 3

Correlations for key study variables

\begin{tabular}{|c|c|c|c|c|c|c|c|c|c|c|c|c|}
\hline Variable & 1 & 2 & 3 & 4 & 5 & 6 & 7 & 8 & 9 & 10 & 11 & 12 \\
\hline 1. Age $(\mathrm{T})$ & - & -.01 & .12 & $.19 *$ & $-.29 * *$ & .06 & $-.28 * *$ & -.15 & -.07 & $.25 * *$ & .13 & $.33^{* * *}$ \\
\hline 2. Gender $(\mathrm{T})$ & -.03 & - & .09 & $.29 * * *$ & .09 & .08 & .01 & .02 & .10 & $.23 * *$ & $.26 * *$ & .05 \\
\hline 3. Internet Use (T) & .14 & .04 & - & .11 & $-.24 * *$ & .14 & .01 & .04 & -.07 & $.20 *$ & .11 & .07 \\
\hline 4. Cell Phone Use (T) & $.28 *$ & .12 & .22 & - & -.01 & .12 & .01 & $.27 * *$ & $.27 * *$ & $.43^{* * *}$ & $.36 * * *$ & $.43 * * *$ \\
\hline 5. Disclosure (T) & -.14 & .04 & $-.36 * *$ & -.09 & - & -.14 & $.36 * * *$ & $.29 * * *$ & .09 & -.08 & -.03 & $-.26 * *$ \\
\hline 6. Secrecy (T) & -.03 & .09 & .07 & -.05 & -.02 & - & -.15 & -.14 & .06 & .08 & .12 & .13 \\
\hline 7. Rules (P) & $-.35 * *$ & .07 & $-.36 * *$ & -.09 & $.29 *$ & $-.28 *$ & - & $.49 * * *$ & $.36 * * *$ & -.01 & .04 & -.04 \\
\hline 8. Solicitation $(\mathrm{P})$ & -.14 & $-.29 *$ & -.12 & .19 & .13 & $-.33 *$ & $.38 * *$ & - & $.31 * * *$ & .10 & .12 & .06 \\
\hline 9. Covert (P) & -.24 & .01 & .05 & .01 & -.18 & -.13 & $.27 *$ & .20 & - & .11 & .16 & .15 \\
\hline 10. Cyberbullying Behaviors (T) & $.28 *$ & .05 & .11 & $.53^{* * *}$ & -.02 & -.05 & -.05 & $.28 *$ & .12 & - & $.62 * * *$ & $.59 * * *$ \\
\hline 11. Cyber Victimization (T) & .09 & .11 & -.02 & $.27 *$ & .06 & -.23 & .08 & $.30 *$ & $.27 *$ & $.54 * * *$ & - & $.50 * * *$ \\
\hline 12. Risky Internet Behaviors (T) & $.39 * *$ & -.05 & .11 & $.60 * * *$ & -.13 & .00 & -.14 & .18 & .25 & $.63^{* * *}$ & $.50 * * *$ & - \\
\hline
\end{tabular}

Note. Correlations for mothers are above and fathers are below the diagonal. T denotes adolescent report measures; P denotes parent report measures; * $=p<.05 ; * *=p<.01 ; * * *=p<.001$ 


\section{Table 4}

Mother hierarchical, and father stepwise regressions predicting adolescents' cyber risks

\begin{tabular}{|c|c|c|c|c|c|c|c|c|c|c|c|c|c|c|c|c|c|c|}
\hline & \multicolumn{6}{|c|}{ Adolescent Risky Internet Behaviors } & \multicolumn{6}{|c|}{ Adolescent Cyberbullying Behaviors } & \multicolumn{6}{|c|}{ Adolescent Cyber Victimization } \\
\hline & \multicolumn{3}{|c|}{ Mother - Dyads } & \multicolumn{3}{|c|}{ Father - Dyads } & \multicolumn{3}{|c|}{ Mother-Dyads } & \multicolumn{3}{|c|}{ Father-Dyads } & \multicolumn{3}{|c|}{ Mother-Dyads } & \multicolumn{3}{|c|}{ Father-Dyads } \\
\hline & $\mathrm{R}^{2^{*}}$ & F Change & Beta & $\mathrm{R}^{2^{*}}$ & F Change & Beta & $\mathrm{R}^{2^{*}}$ & F Change & Beta & $\mathrm{R}^{2^{*}}$ & F Change & Beta & $\mathrm{R}^{2^{*}}$ & F Change & Beta & $\mathrm{R}^{2^{*}}$ & F Change & Beta \\
\hline Step 1 & .23 & $11.57 * *$ & & .38 & $11.20^{* *}$ & & .24 & $11.79 * * *$ & & .27 & $19.59 * * *$ & & .15 & $7.05^{* * *}$ & & .07 & 4.91* & \\
\hline Age & & & $.23^{* *}$ & & & $.34 * *$ & & & $.18 *$ & & & & & & .08 & & & \\
\hline Internet Use & & & -.04 & & & .03 & & & .12 & & & & & & .04 & & & \\
\hline Cell Phone Use & & & $.39 * *$ & & & $.46^{* *}$ & & & $.35 *$ & & & $.53^{* * *}$ & & & $.27 * *$ & & & \\
\hline Step 2 & .26 & 1.97 & & .48 & $9.74^{* *}$ & & .21 & .05 & & & & & .13 & .38 & & & & \\
\hline Teen Disclosure & & & $-.23 * *$ & & & & & & -.03 & & & & & & -.04 & & & \\
\hline Teen Secrecy & & & .06 & & & & & & .02 & & & & & & .08 & & & \\
\hline Parent Internet Rules & & & .08 & & & & & & .01 & & & & & & .03 & & & \\
\hline Parent Internet Solicitation & & & .02 & & & & & & .03 & & & & & & .04 & & & $.30 *$ \\
\hline Parent Internet Covert Monitoring & & & -.16 & & & $.28 *$ & & & .00 & & & & & & .04 & & & \\
\hline Step 3 & .28 & 4.13* & & .53 & $6.10^{*}$ & & & & & & & & & & & & & \\
\hline Mother Covert X Teen Gender & & & $.24^{*}$ & & & & & & & & & & & & & & & \\
\hline Father Covert X Teen Age & & & & & & $.27 *$ & & & & & & & & & & & & \\
\hline
\end{tabular}

Note. Mothers' models were hierarchical and fathers' were stepwise which is why parameters are missing from father models, $\mathrm{R}^{2^{*}}=$ adjusted $R$;

Beta's are from the final step of the regression; Non-significant 2-way interactions from the final model were excluded from the table; ${ }^{*} p<.05$; $* * p$ $<.01 ; * * * \mathrm{p}<.001$ 


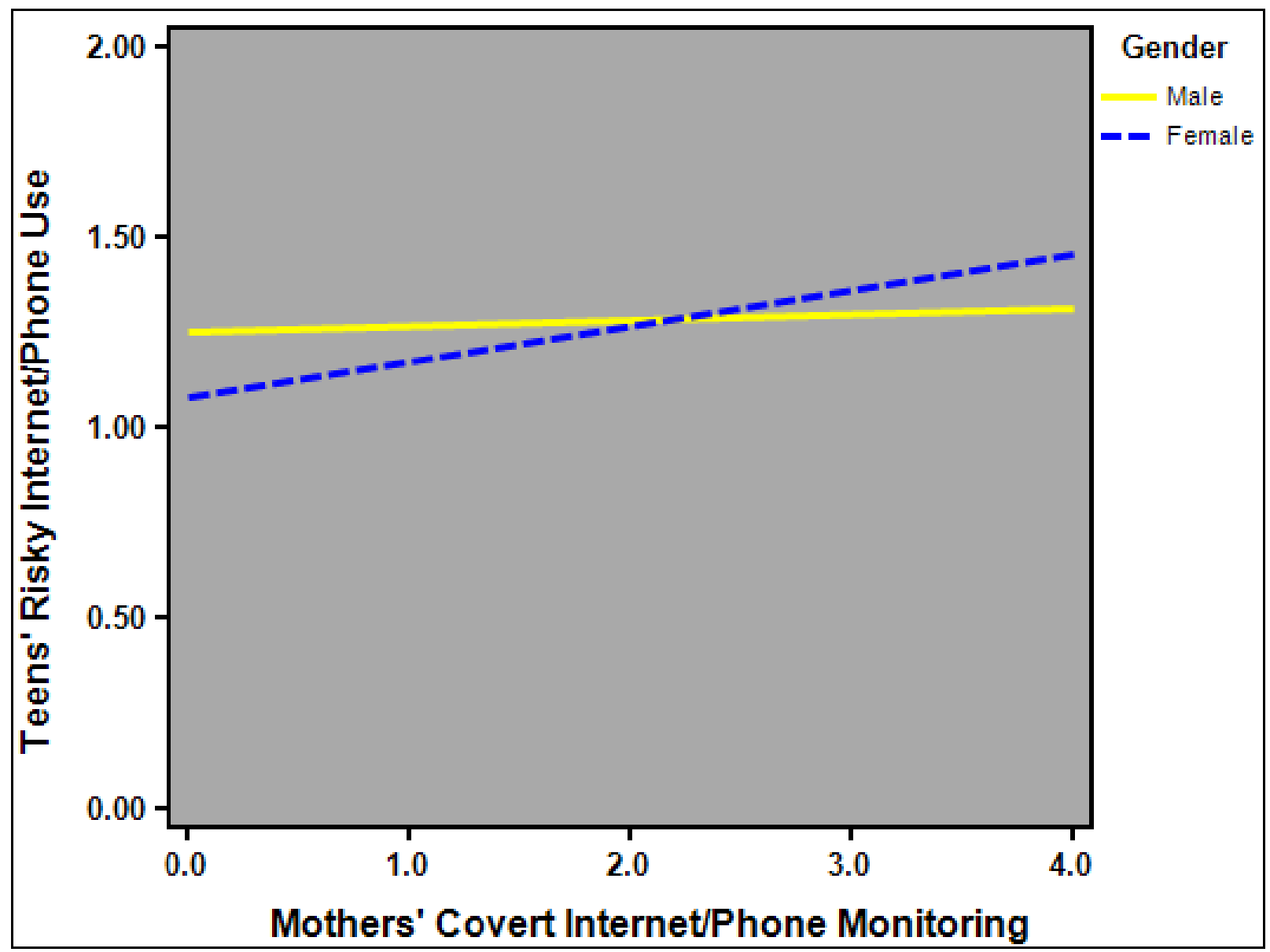

Figure 1. Associations between mothers' covert internet/phone monitoring and adolescents' risky internet/phone behaviors by adolescent gender interaction graph. 


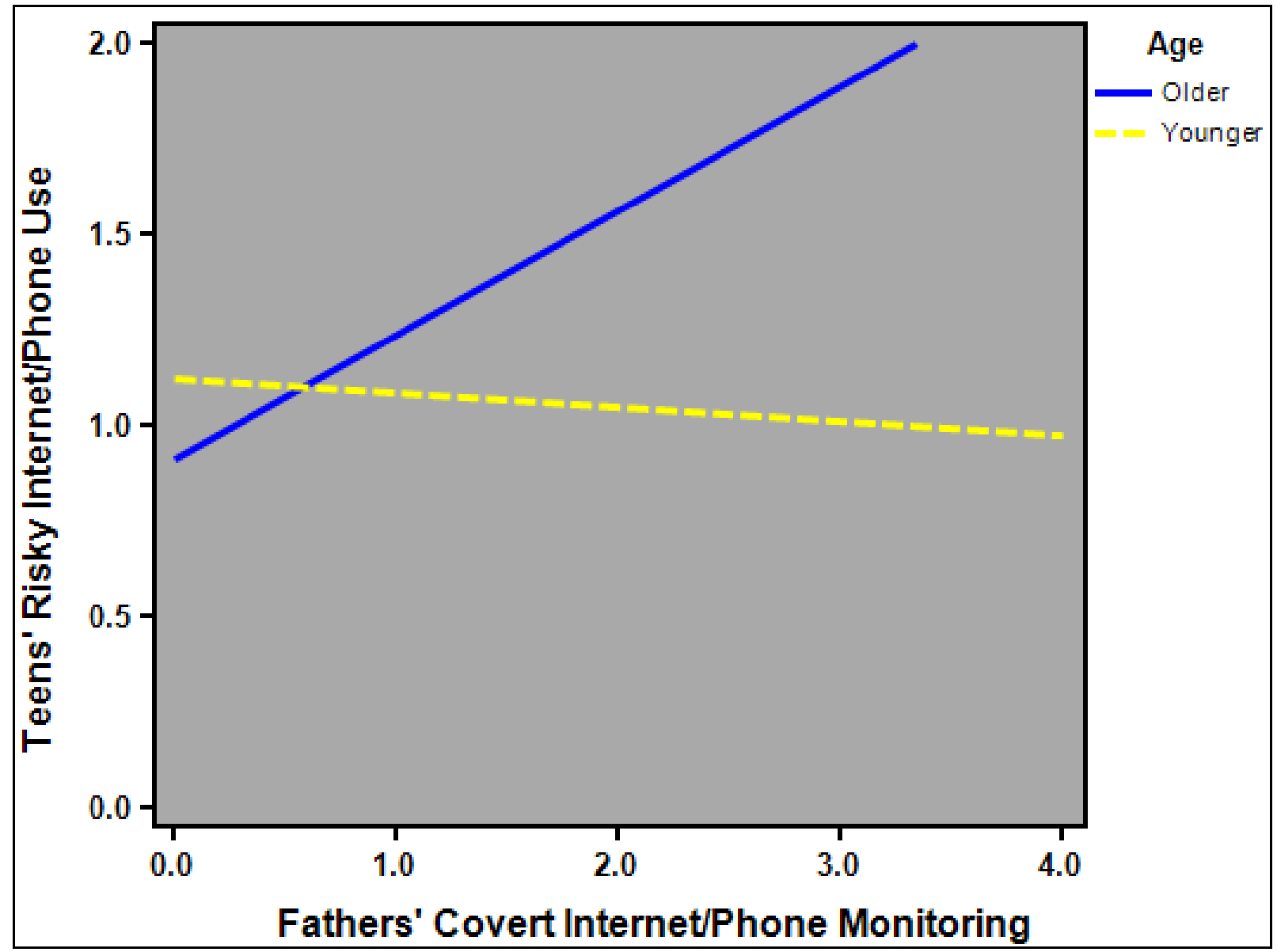

Figure 2. Associations between fathers' covert internet/phone monitoring and adolescents' risky internet/phone behaviors by adolescent age interaction graph. 


\section{Appendix A}

\section{Observation Measures}

Parents' Shared Knowledge of Cyber Victimization. Adolescents and their parents participated in a thirty-three minute observational discussion task. The discussion was divided into five topics including family life, food and eating behaviors, internet and cell phone use, alcohol use, and civic involvement. The discussion of family life was a five-minute discussion while the remaining four topics were seven minutes each. The present study focused on the seven-minute internet and cell phone discussion. Parent-adolescent discussions were conducted separately for mothers and fathers.

The discussions were semi-structured, using a cue card method. Parents and adolescents

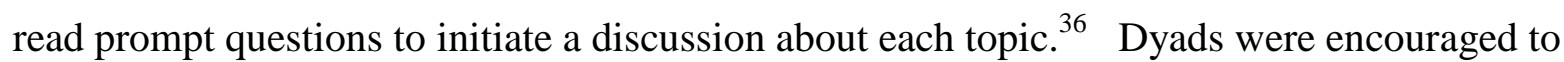
discuss all of the cards within each topic, however families were instructed to discuss the topics at their own pace. The five internet discussion cues were "Let's talk about...." (a) (teen:) “The different ways that people in our family use the internet. How often are we on the internet? How important is internet to our lives?”, (b) (parent:) “How do families make decisions about which websites teens should and should not visit?”, (c) (parent:) “Are there any potential problems or dangers associated with communicating with people online or through cell phone texting?”, (d) (teen:) "How can teens use the internet or cell phone texting to be mean or hurt other teens' feeling?”, (e) (parent:) “What parents do if they find out their child is being bullied online or through texts." It is important to note that neither the directions nor the prompt questions required that adolescents or parents discuss the teens' own experiences with cyber victimization. 


\section{Appendix B}

\section{Parental Shared Cyber Knowledge Coding}

Trained coders coded the videotaped discussions for parents’ shared knowledge of cyber victimization. Discussions were coded for parental shared knowledge of victimization initiated by either the parent or the teen. Codable statements consisted of conversations in which the parents and adolescents acknowledged the cyber victimization. For instance parents stated, "We’ve had the bullying issue with your cell phone...” and the adolescents confirmed; or adolescents stated, “That happened to me and a lot of my friends...” and parents confirmed. Separate codes were assigned when parents asked adolescents if they had been bullied, and when adolescents stated that they had been victimized and the parents failed to follow with discussions about their knowledge of the event. The shared knowledge codes were utilized in subsequent analyses, with a subsample of adolescents who reported cyber victimization, to assess predictors of parents’ shared knowledge of cyber victimization.

Coders were trained to rate each parent-teen interaction for the presence (1) or absence (0) of parent and/or adolescent discussion of the adolescents' experiences with cybervictimization. Parent-adolescent discussions were coded directly from the videos; however coded exchanges were also transcribed for inter-rater verification. Fifteen videos were used to train coders to reliability standards. Inter-rater reliability was assessed using Kappa coefficients according to previously established guidelines. ${ }^{37}$ Training was successful when coders reached acceptable Kappas of between .70 and 1.0. ${ }^{37}$ Consistent with previous research using this observational method, 33\% of parent-adolescent discussions were double-coded. ${ }^{38}$ Inter-rater reliability was monitored throughout the coding process to eliminate potential "coder drift”, and 
coding disagreements were resolved in consensus meetings. The consensus codes were used in subsequent analyses.

Final inter-rater reliability for the discussion of shared knowledge code was a Kappa of .83 (see Table 3 for percentage of shared knowledge codes). 


\section{Appendix C}

\section{Originally Proposed Analyses}

\section{Research Question 1}

What are the characteristics of adolescents who report cyber victimization, and parents who know their teen has been cyber bullied?

Hypothesis 1a. Consistent with previous research, it is hypothesized that older adolescents, female adolescents, and those who spend more time on the Internet will report higher rates of cyber victimization.

Bivariate correlations were performed to assess associations between cyber victimization and adolescent age, gender and time spent on the Internet. Consistent with previous research, adolescents who were female $(r=.22, p=.01)$ and spent more time on the internet $(r=.43, p<$ .001) were more likely to have higher rates of cyber victimization. Age was not significantly associated with cyber victimization. Adolescent reports of cyber victimization were positively associated with engagement in cyberbullying $(r=.63, p<.001)$. Correlations between adolescent variables can be seen in Table 4.

Previous researchers have identified key variables that distinguish victims from nonvictims, including gender, age and time spent on the internet. The present study's sample was similar to prior studies in that adolescents were more likely to report victimization if they were female, and reported more victimization with increased time on the internet. Adolescents who engaged in cyberbullying behaviors were also more likely to be cyber victims.

Hypothesis 1b. Consistent with previous research, it is hypothesized that mothers, parents of younger adolescents, and parents of female adolescents will be more likely to know that their adolescent has been the victim of cyberbullying. 
A series of t-tests and chi-square analyses were performed to examine differences in adolescents’ age, adolescents’ gender, and parent gender within families who discussed shared knowledge compared to families who did not. Two independent-samples t-tests were conducted to assess adolescent victims’ age differences in discussions of shared knowledge of cyber victimization. There were no significant differences in the age of adolescents who discussed shared knowledge $\left(M_{\text {mothers }}=14.78, S D=1.68 ; M_{\text {fathers }}=14.00, S D=1.41\right)$ compared to those who did not $\left(M_{\text {mothers }}=14.60, S D=1.68 ; M_{\text {fathers }}=14.46, S D=1.65\right)$; mother-teen dyads: $t(88)$ $=-.46, p=.65$ and father-teen dyads: $t(27)=.65, p=.52$. Chi-square analyses indicated no significant differences in shared knowledge of victimization with respect to parents' gender, $\chi^{2}$ $(1, n=119)=.02, p=.88, \mathrm{phi}=.01$, or adolescents' gender [mother-teen dyads: $\chi^{2}(1, n=90)=$ 3.11, $p=.08$, phi $=.19$, father-adolescent dyads: $\chi^{2}(1, n=29)=3.48, p=.06$, phi $\left.=.35\right]$.

The present study utilized a seven-minute internet discussion task to assess parents’ knowledge of adolescents' cyber victimization. Discussions were coded for parent-adolescent communication about adolescents' victimization. It was hypothesized that families with younger adolescents would be more likely to discuss knowledge of victimization; however the results showed no significant age differences in the likelihood of discussing shared knowledge. Motheradolescent dyads were expected to discuss shared knowledge more than father-adolescent dyads, and female adolescents were expected to be more likely to discuss knowledge with their parents. The present study found no significant parent or adolescent gender differences in the discussion of shared knowledge.

The lack of age and gender differences may be associated with the small percentage of families that actually discussed cyber victimization (Table 3). The findings may indicate that adolescents are not discussing victimization with their parents. Researchers should examine why 
teens are not talking to their parents about their experiences with victimization, and assess correlates that may facilitate family discussions (i.e., open communication). The null findings may also be a result of methodological limitations. Limitations exist in the coding scheme utilized in the present study, which may have decreased the number of families coded as having discussed shared knowledge. Parents were given credit for knowledge of victimization, only when the child confirmed or elaborated on parents' statements. There may have been parents who knew a teen was victimized and discussed knowledge, but the adolescent failed to confirm. There were also instances in which an adolescent told his or her parent about an experience with victimization; however the discussion was not coded as shared knowledge. 


\section{Research Question 2}

Is parental knowledge of cyber victimization associated with parent information-gathering and teen information-management strategies?

\section{Hypothesis 1.}

It is hypothesized that:

a. Parents are more likely to have knowledge of cyber victimization when they actively seek information about adolescents’ internet behaviors through rules, solicitation, or indirect strategies.

b. Parents are more likely to have knowledge of cyber victimization when their adolescents disclose more, and keep fewer secrets about internet behaviors.

To examine whether parental monitoring strategies and adolescent information management strategies predicted shared knowledge of victimization within mother-adolescent dyads with adolescents, a logistic regression model was run for the sub-sample of teens who reported any victimization $(N=90)$

In the first step of the model, mothers’ shared knowledge of adolescent cyber victimization was regressed onto adolescent age and gender. Adolescent information management strategies, disclosure and secrecy, were entered at the second step. In the final step, parental monitoring strategies (rules, solicitation, and covert) were entered. Neither parental monitoring strategies nor adolescent information management strategies significantly predicted discussion of mothers' shared knowledge of cyber victimization (Table 4). The subsample of father-adolescent dyads with adolescents who reported victimization was not examined due to a very small sample size $(N=29)$. 
The present study examined parents’ knowledge of adolescents’ cyber victimization through parent-adolescent discussions of internet/phone use with a sample of adolescents who reported cyber victimization. Parent-adolescent dyads were presented with two discussion prompts about cyberbullying, "How can teens use the internet or cell phone texting to be mean or hurt other teens' feeling?" and "Let's talk about what parents do if they find out their child is being bullied online or through texts." The discussion prompts were not specific to the families' experiences with cyberbullying; however we expected that families would spontaneously discuss their own experiences. Parent-adolescent responses were coded for discussions of shared knowledge, and the results showed no significant associations between parental monitoring of internet/phone use, or adolescent disclosure about internet/phone use, and discussions of shared knowledge.

The lack of significant findings may be associated with our small sample size $(N=90)$ and the limited number of mother-adolescent dyads that were coded as having discussed victimization $(n=23)$. The findings may indicate that adolescents do not talk to their parents about their experiences with cyberbullying. Researchers should examine the reasons that adolescents do not talk to their parents about cyber victimization. Similar to general adolescent disclosure research, adolescents may be trying to avoid getting into trouble, ${ }^{17}$ or may believe that telling their parents would not be beneficial. In fact, adolescents have reported not telling their parents about cyberbullying for fear of losing their online privileges. ${ }^{39}$ Future research may benefit from studying adolescents' beliefs about the harmfulness of the cyberbullying, as well as other correlates that may increase family discussions about victimization.

The null findings may also be due to limitations in our methodology and coding scheme. Families were given credit for talking about a teen’s experience with cyber victimization when 
both the parent and teen acknowledged that the event occurred. We may have missed parents who knew their teen was bullied if the teen did not confirm a parent's statement. Another limitation was the order in which cue cards were presented, the questions that would elicit parent-adolescent communication about their own experiences were the last two cards presented, in the seven-minute task (Appendix F). Families were instructed to talk as much as they wanted about each card and there were families that spent more time discussing the earlier cards and did not reach the last two, or the final card. However, we did not document the frequency of these occurrences. Future studies utilizing this methodology may benefit from developing a way to track when families do not talk about the key cue cards. Having a card specific to a family's experience with cyberbullying may be beneficial for future studies. 
Table 1

Adolescent cyber descriptive statistics

\begin{tabular}{lcc}
\hline Measure & M (SD) & N (\%) \\
\hline Internet in Home & & 97 (95.5) \\
Has own computer & & 93 (60) \\
Has phone with internet capabilities & 3.48 or $1-3$ hours $(0.90)$ & \\
Adolescent internet use & 3.07 or 1-2 hours (1.07) & \\
Adolescent cell phone use & $1.40(0.63)$ & \\
Adolescent engagement in cyberbullying behaviors & $1.71(0.93)$ \\
Adolescent cyber victimization & $1.32(0.58)$ \\
\hline Adolescent risky internet behaviors & \\
\hline
\end{tabular}

Note: Percentage of teens who reported cyberbullying behaviors and cyber victimization were obtained utilizing Schenk and Fremouw’s (2012) criteria. 
PARENTAL MONITORING, YOUTH DISCLOSURE, AND CYBER RISKS

Table 2

Adolescent experience with cyberbullying

\begin{tabular}{lccc}
\hline Measure & None (\%) & Low (\%) & Criteria (\%) \\
\hline Adolescent engagement in cyberbullying behaviors & 52.5 & 24.1 & 23.4 \\
Adolescent cyber victimization & 35.5 & 22.7 & 41.8 \\
\hline
\end{tabular}

Note: Percentages of adolescents who engaged in cyberbullying behaviors and were cyber victims were obtained utilizing Schenk and Fremouw's (2012) criteria. 
PARENTAL MONITORING, YOUTH DISCLOSURE, AND CYBER RISKS

Table 3

Parents' discussions of shared knowledge of cyber victimization

$\begin{array}{ll}\text { Measure } & \%\end{array}$

Discussion of shared knowledge with mothers $(N=90)$

Discussion of shared knowledge with fathers $(N=29)$ 
PARENTAL MONITORING, YOUTH DISCLOSURE, AND CYBER RISKS

Table 4

Correlations between adolescent demographic variables, cyber victimization, and cyberbullying

\begin{tabular}{lcccc}
\hline Variable & 2 & 3 & 4 & 5 \\
\hline 1. Gender & -.02 & $.17^{* *}$ & $.22^{* *}$ & $.19^{*}$ \\
2. Age & 1.0 & $.18^{*}$ & .11 & $.24^{* *}$ \\
3. Weekly Internet Use & & & $.43^{* * *}$ & $.45^{* * *}$ \\
4. Cyber Victimization & 1.0 & 1.0 & $.63^{* * *}$ \\
5. Cyberbullying & & & 1.0 \\
\hline
\end{tabular}

Note. ${ }^{*} p<.05 ; * * p<.01 ; * * * p<.001$ 
Table 5

Logistic regression predicting mother-adolescent victim dyads' shared knowledge of cyber victimization $(N=90)$

\begin{tabular}{|c|c|c|c|c|c|c|c|c|}
\hline & \multirow[t]{2}{*}{$B$} & \multirow[t]{2}{*}{ S.E. } & \multirow[t]{2}{*}{ Wald } & \multirow[t]{2}{*}{$d f$} & \multirow[t]{2}{*}{$p$} & \multirow[t]{2}{*}{$\begin{array}{l}\text { Odds } \\
\text { Ratio }\end{array}$} & \multicolumn{2}{|c|}{$\begin{array}{l}\text { 95.0\% C.I. for } \\
\text { Odds Ratio }\end{array}$} \\
\hline & & & & & & & Lower & Upper \\
\hline Teen Age & .19 & .17 & 1.22 & 1 & .27 & 1.21 & .86 & 1.69 \\
\hline Teen Gender & -.95 & .63 & 2.27 & 1 & .13 & .39 & .11 & 1.33 \\
\hline Teen Disclosure & .16 & .24 & .45 & 1 & .50 & 1.17 & .74 & 1.88 \\
\hline Teen Secrecy & .26 & .24 & 1.10 & 1 & .30 & 1.29 & .80 & 2.08 \\
\hline Internet Rules & .32 & .37 & .74 & 1 & .39 & 1.38 & .67 & 2.85 \\
\hline Internet Solicitation & .08 & .28 & .08 & 1 & .77 & 1.09 & .62 & 1.89 \\
\hline Internet Covert Monitoring & -.03 & .23 & .01 & 1 & .91 & .97 & .62 & 1.53 \\
\hline
\end{tabular}




\section{Appendix D}

Parent Measures

\section{Demographics}

1. What gender are you?

$$
\square \text { Male } \square \text { Female }
$$

2. What is your relationship to the adolescent in the study?

\begin{tabular}{|c|c|c|}
\hline$\square$ Birth Mother & $\square$ Birth Father & $\square$ Grandparent \\
\hline$\square$ Step-Mother & $\square$ Step-Father & $\square$ Other relative (aunt, uncle, \\
\hline$\square$ Adoptive Mother & $\square$ Adoptive Father & brother, sister, cousin, etc.) \\
\hline \multicolumn{3}{|c|}{$\square$ Other relative (specify): } \\
\hline
\end{tabular}

3. What is your present marital status?

$\square$ Married
$\square$ Divorced/Separated
$\square$ Widowed
$\square$ Single, never married
$\square$ Living with a romantic partner

4. For how long have you had your present marital status? years

5. How old are you? (years) What is your birthday? (Month/Day/Year)

6. What is your ethnicity (Please circle)?

African-American/Black

Asian-American/Pacific Islander

Caucasian/White
Hispanic/Latino

Native American

Other (describe) 
7. What is the highest level of education you have completed?

$\square \quad$ Completed $8^{\text {th }}$ grade

$\square \quad$ Completed high school

$\square \quad$ Completed college

$\square \quad$ Business or Technical School

$\square \quad$ Graduate degree (doctor, lawyer, $\mathrm{PhD}$ )

8. Are you currently employed?

$$
\square \text { Yes, full-time } \quad \square \text { Yes, part-time } \quad \square \text { No }
$$

9. Are you a student?

$$
\square \text { Yes, full-time } \quad \square \text { Yes, part-time } \quad \square \text { No }
$$

10. Which best describes your total yearly household income?

$$
\begin{aligned}
& \square \$ 11,999 \text { or less } \\
& \square \$ 12,000 \text { to } 24,999 \\
& \square \$ 25,000 \text { to } 49,999 \\
& \square \$ 50,000 \text { to } 74,999 \\
& \square \$ 75,000 \text { to } 99,999 \\
& \square \$ 100,000 \text { to } 149,999 \\
& \square \$ 150,000 \text { or above }
\end{aligned}
$$




\section{Parental Internet and Cell Phone Monitoring Strategies}

\section{Parental Rules}

For the next set of questions, please rate the extent to which your family has rules for each issue listed below, using the following scale:

\begin{tabular}{|c|c|c|c|c|c|}
\hline & $\begin{array}{c}\text { No rules or } \\
\text { expectations }\end{array}$ & & & & $\begin{array}{l}\text { Firm, } \\
\text { clear } \\
\text { rules }\end{array}$ \\
\hline 1. How long your child is allowed to be online & 1 & 2 & 3 & 4 & 5 \\
\hline $\begin{array}{l}\text { 2. What your child is allowed to post on social } \\
\text { websites (FACEBOOK)? }\end{array}$ & 1 & 2 & 3 & 4 & 5 \\
\hline $\begin{array}{l}\text { 3. How much time my child spends on their cell } \\
\text { phone }\end{array}$ & 1 & 2 & 3 & 4 & 5 \\
\hline $\begin{array}{l}\text { 4. The types of messages my child is allowed to } \\
\text { text }\end{array}$ & 1 & 2 & 3 & 4 & 5 \\
\hline
\end{tabular}

\section{Solicitation}

\begin{tabular}{|c|c|c|c|c|c|}
\hline $\begin{array}{l}\text { How often do you talk to your teenager or } \\
\text { ask about... }\end{array}$ & $\begin{array}{c}\text { Never } \\
1\end{array}$ & 2 & 3 & 4 & $\begin{array}{c}\text { Always } \\
5\end{array}$ \\
\hline $\begin{array}{l}\text { 1. The types of pictures and comments } \\
\text { he/she puts on his/her social networking site } \\
\text { (FACEBOOK) }\end{array}$ & 1 & 2 & 3 & 4 & 5 \\
\hline $\begin{array}{l}\text { 2. What he/she talks about on the phone } \\
\text { with friends? }\end{array}$ & 1 & 2 & 3 & 4 & 5 \\
\hline 3. If he/she visits adult websites & 1 & 2 & 3 & 4 & 5 \\
\hline $\begin{array}{l}\text { 4. If he/she is talking to individuals online } \\
\text { who he/she doesn't know }\end{array}$ & 1 & 2 & 3 & 4 & 5 \\
\hline $\begin{array}{l}\text { 5. The types of text messages he/she sends } \\
\text { on his/her cell phone }\end{array}$ & 1 & 2 & 3 & 4 & 5 \\
\hline 6. If he/she texts sexual messages or photos & 1 & 2 & 3 & 4 & 5 \\
\hline
\end{tabular}




\begin{tabular}{|c|c|c|c|c|c|}
\hline on his/her cell phone & & & & & \\
\hline $\begin{array}{l}\text { 7. If he/she texts mean or hurtful messages } \\
\text { on his/her cell phone }\end{array}$ & 1 & 2 & 3 & 4 & 5 \\
\hline
\end{tabular}

\section{Covert Monitoring}

\begin{tabular}{|l|c|c|}
\hline Have you ever, checked your child's... & Yes & No \\
\hline 1. Email to get information about what your teen is doing or saying to friends & $\mathrm{Y}$ \\
\hline 2. Cell phone to get information about what your teen is doing or saying to friends & $\mathrm{N}$ & $\mathrm{N}$ \\
\hline $\begin{array}{l}\text { 3. Do you use social networking sites (such as FACEBOOK) to monitor your child's } \\
\text { behavior? }\end{array}$ & $\mathrm{Y}$ & $\mathrm{N}$ \\
\hline 4. Do you monitor your child's cell phone use? & $\mathrm{Y}$ & $\mathrm{N}$ \\
\hline
\end{tabular}




\section{Appendix E}

\section{Adolescent Measures}

\section{Demographics}

1. What gender are you?

$\square$ Male $\quad \square$ Female

2. How old are you? (years) What is your birthday?

(Month/Day/Year)

3. What is your grade in school? $6^{\text {th }} 7^{\text {th }} 8^{\text {th }} 9^{\text {th }} \quad 10^{\text {th }} 11^{\text {th }} 12^{\text {th }}$

4. School grades (Please circle):

$\square$ Mostly A's

$\square$ Some A's some B's

$\square$ Mostly B's

$\square$ Some B's some C’s

$\square$ Mostly C’s

$\square$ Some C's some D's

$\square$ Mostly D’s or lower

5. What is your ethnicity (Please circle)?
$\square$ African-American/Black
$\square$ Hispanic/Latino
$\square$ Asian-American/Pacific Islander $\square$ Native American
$\square$ Caucasian/White
$\square$ Other (describe)

6. Who currently lives in your home (Circle all that apply)?
$\square$ mother (birth or adopted)
$\checkmark$ stepmother
$\square$ father (birth or adopted)
$\square$ stepfather 
$\square$ brothers/sisters? (ages of siblings)

$\square$ other adults (who?)

7. What is the highest level of schooling your mother (or female guardian) completed?

8. What is the highest level of schooling your father (or male guardian) completed?

Completed $8^{\text {th }}$ grade

Completed high school

Completed college

Graduate degree (doctor, lawyer, $\mathrm{PhD}$ )

Don't know or unsure
Completed $8^{\text {th }}$ grade

Completed high school

Completed college

Graduate degree (doctor, lawyer, $\mathrm{PhD}$ )

Don’t know or unsure

At what type of JOB does your MOTHER work? At what type of JOB does your FATHER work?

\begin{tabular}{|l|c|c|}
\hline & Yes & No \\
\hline 1. Do you have your own computer? & $\mathrm{Y}$ & $\mathrm{N}$ \\
\hline 2. Does your home have internet? & $\mathrm{Y}$ & $\mathrm{N}$ \\
\hline 3. Do you have a phone with internet capabilities? & $\mathrm{Y}$ & $\mathrm{N}$ \\
\hline
\end{tabular}




\section{Internet and Cell Phone Use Questions}

How many hours per day do you spend on the internet?

\begin{tabular}{|l|c|c|c|c|c|}
\hline Weekday & None & Less than 1 & $1-2$ & $3-5$ & $6^{+}$ \\
\hline Weekend & None & Less than 1 & $1-2$ & $3-5$ & $6+$ \\
\hline
\end{tabular}

How many hours per day do you spend on your cell phone?

\begin{tabular}{|l|c|c|c|c|c|}
\hline Weekday & None & Less than 1 & $1-2$ & $3-5$ & $6^{+}$ \\
\hline Weekend & None & Less than 1 & $1-2$ & $3-5$ & $6^{+}$ \\
\hline Texting & None & Less than 1 & $1-2$ & $3-5$ & $6+$ \\
\hline Making Calls & None & Less than 1 & $1-2$ & $3-5$ & $6+$ \\
\hline Surfing the Internet & None & Less than 1 & $1-2$ & $3-5$ & $6+$ \\
\hline
\end{tabular}

\section{$\underline{\text { Adolescent Cyber Victimization Questions }}$}

\begin{tabular}{|c|c|c|c|c|c|c|}
\hline In the last year: & 0 & 1 & $2-3$ & $4-7$ & $\begin{array}{l}8- \\
14\end{array}$ & $\begin{array}{l}15 \text { or } \\
\text { more }\end{array}$ \\
\hline $\begin{array}{l}\text { 1. How many times has someone posted damaging or } \\
\text { embarrassing information (secrets) about you through chat rooms } \\
\text { or on social networking sites (for instance, on your or other } \\
\text { peoples “wall”)? }\end{array}$ & 0 & 1 & $2-3$ & $4-7$ & $\begin{array}{l}8- \\
14\end{array}$ & $\begin{array}{l}15 \text { or } \\
\text { more }\end{array}$ \\
\hline $\begin{array}{l}\text { 2. How many times have you received harassing, mean, or nasty } \\
\text { text-messages? }\end{array}$ & 0 & 1 & $2-3$ & $4-7$ & $\begin{array}{l}8- \\
14\end{array}$ & $\begin{array}{l}15 \text { or } \\
\text { more }\end{array}$ \\
\hline $\begin{array}{l}\text { 3. How many times has someone posted hurtful comments about } \\
\text { you on the internet through chat rooms or on social networking } \\
\text { sites (on your or other peoples “wall”)? }\end{array}$ & 0 & 1 & $2-3$ & $4-7$ & $\begin{array}{l}8- \\
14\end{array}$ & $\begin{array}{l}15 \text { or } \\
\text { more }\end{array}$ \\
\hline 4. How many times has someone posted hurtful pictures of you & 0 & 1 & $2-3$ & $4-7$ & $8-$ & 15 or \\
\hline
\end{tabular}




\begin{tabular}{|c|c|c|c|c|c|c|}
\hline without your permission? & & & & & 14 & more \\
\hline $\begin{array}{l}\text { 5. How many times has someone started rumors or gossiped about } \\
\text { you through chat rooms or on social networking sites (for } \\
\text { instance, on your or other peoples "wall”)? }\end{array}$ & 0 & 1 & $2-3$ & $4-7$ & $\begin{array}{l}8- \\
14\end{array}$ & $\begin{array}{l}15 \text { or } \\
\text { more }\end{array}$ \\
\hline $\begin{array}{l}\text { 6. How many times has someone pretended to be someone they } \\
\text { were not and posted or sent material to damage your friendships } \\
\text { or reputation, and/or hurt or embarrass you? }\end{array}$ & 0 & 1 & $2-3$ & $4-7$ & $\begin{array}{l}8- \\
14\end{array}$ & $\begin{array}{l}15 \text { or } \\
\text { more }\end{array}$ \\
\hline $\begin{array}{l}\text { 7. How many times has someone started rumors or gossiped about } \\
\text { you through text messaging }\end{array}$ & 0 & 1 & $2-3$ & $4-7$ & $\begin{array}{l}8- \\
14\end{array}$ & $\begin{array}{l}15 \text { or } \\
\text { more }\end{array}$ \\
\hline
\end{tabular}

\section{Adolescent Internet and Cell Phone Information Management Strategies}

\section{$\underline{\text { Disclosure Items }}$}

\begin{tabular}{|c|c|c|c|c|c|c|}
\hline $\begin{array}{l}\text { How often do you tell your parents about the } \\
\text { following activities (without them asking)...If you } \\
\text { never do the activity, check “I don't do this” }\end{array}$ & $\begin{array}{c}\text { Never } \\
1\end{array}$ & 2 & 3 & 4 & $\begin{array}{l}\text { Always } \\
\qquad 5\end{array}$ & $\begin{array}{c}\text { I } \\
\text { don't } \\
\text { do } \\
\text { this }\end{array}$ \\
\hline $\begin{array}{l}\text { 1. The types of pictures and comments you put on } \\
\text { your social networking site (FACEBOOK) }\end{array}$ & 1 & 2 & 3 & 4 & 5 & 6 \\
\hline 2. What you talk about on the phone with friends? & 1 & 2 & 3 & 4 & 5 & 6 \\
\hline 3. If you visit adult websites & 1 & 2 & 3 & 4 & 5 & 6 \\
\hline 4. Who you talk to online & 1 & 2 & 3 & 4 & 5 & 6 \\
\hline $\begin{array}{l}\text { 5.The types of text messages you send on your } \\
\text { phone }\end{array}$ & 1 & 2 & 3 & 4 & 5 & 6 \\
\hline
\end{tabular}




\section{$\underline{\text { Secrecy Items }}$}

\begin{tabular}{|c|c|c|c|c|c|c|}
\hline $\begin{array}{l}\text { How often do you keep the following activities } \\
\text { secret from parents... If you never do the } \\
\text { activity, check "I don't do this" }\end{array}$ & Never & 2 & 3 & 4 & Always & $\begin{array}{c}\text { I } \\
\text { don't } \\
\text { do } \\
\text { this }\end{array}$ \\
\hline 1. Who you are talking to online & 1 & 2 & 3 & 4 & 5 & 6 \\
\hline $\begin{array}{l}\text { 2. If you post suggestive or racy pictures and } \\
\text { comments on social networking sites (such as } \\
\text { FACEBOOK) }\end{array}$ & 1 & 2 & 3 & 4 & 5 & 6 \\
\hline 3. If you visit adult websites & 1 & 2 & 3 & 4 & 5 & 6 \\
\hline 4. What you talk about on the phone with friends & 1 & 2 & 3 & 4 & 5 & 6 \\
\hline $\begin{array}{l}\text { 5. The types of text messages you send on your } \\
\text { phone }\end{array}$ & 1 & 2 & 3 & 4 & 5 & 6 \\
\hline
\end{tabular}




\section{Appendix F}

Discussion Cue Cards

\section{Card 1 - Teen}

Let's talk about the different ways that people in our family use the internet. How often are we on the internet? How important is internet to our lives?

\section{Card 2 - Parent}

How do families make decisions about which websites teens should and should not visit?

\section{Card 3 - Parent}

Are there any potential problems or dangers associated with communicating with people online or through cell phone texting? Let's talk about this.

Card 4 - Teen

How can teens use the internet or cell phone texting to be mean or hurt other teens' feeling?

Card 5 - Parent

Let's talk about what parents do if they find out their child is being bullied online or through texts. 